UDC 631.11

DOI: 10.46666/2021-4.2708-9991.14

https://www.jpra-kazniiapk.kz

\title{
GRAIN MARKETING SYSTEM AS A CONDITION FOR THE FOOD MARKET STABILITY
}

\author{
АСТЫҚТЫ ӨТКІЗУ ЖҮЙЕСІ АЗЫҚ-ТҮЛІК НАРЫҒЫ ТҰРАҚТЫЛЫҒЫНЫҢ \\ ШАРТЫ РЕТІНДЕ
}

\section{СИСТЕМА СБЫТА ЗЕРНА КАК УСЛОВИЕ СТАБИЛЬНОСТИ ПРОДОВОЛЬСТВЕННОГО РЫНКА}

\author{
S. MIZANBEKOVA* \\ Dr.E.Sc. RK, RF, Professor \\ B. KALYKOVA \\ C.E.Sc., Associate Professor \\ N. TURASHBEKOV \\ Ph.D student \\ Kazakh National Agrarian Research University, Almaty, Kazakhstan \\ *corresponding author e-mail: salima-49@mail.ru \\ С.К. МИЗАНБЕКОВА* \\ э.ศ.Ә. $K P, P \Phi$, профресcор \\ Б.Б. ҚАЛЫКОВА \\ э.ғ.к., қауымдастырылған профрессор \\ Н.А. ТУРАШБЕКОВ \\ Ph.D докторанты \\ Қазақ ұлттық аграрлық зерттеу университеті, Алматы, Қазақстан \\ *автордың электрондық поштасы: salima-49@mail.ru \\ С.К. МИЗАНБЕКОВА* \\ Ә.э.н. $Р К, Р Ф$, профрессор \\ Б.Б. КАЛЫКОВА \\ к.э.н., ассоциированный профрессор \\ Н.А.ТУРАШБЕКОВ \\ докторант Ph.D \\ Казахский национальный аграрный исследовательский университет, \\ Алматы, Казахстан \\ *электронная почта автора: salima-49@mail.ru
}

\begin{abstract}
The efficient functioning of grain market contributes to the food security of the country. The aim - the issue of improving the grain marketing system is considered. Methods - comparative analysis, statistical and economic, logical, generalization. Results - assessment of the potential of grain resources in the context of the development priorities of the agro-industrial complex is presented. It is noted that currently there are changes in the volume and structure of grain sales channels: a decrease in absolute indicators and relative share of its sales to the State and increased sales on free market. The situation in storage of grain is shown, which indicates that in the work of large elevators, trends associated with functioning of agricultural holdings, the emergence of large grain companies and transnational corporations are indicated, which are mainly located in the territory of grain-growing regions. At the same time, many rural commodity producers do not have their own grain storage facilities, they are not united in marketing cooperatives, which does not give them the opportunity to form large commercial lots of high quality grain crops, to reduce distribution costs. In addition, they are not sufficiently equipped with grain cleaning and grain drying equipment, as a result, raw materials are not processed to basic conditions. Conclusions - grain industry, which occupies a key position in the economy of the republic, is a complex and dynamically developing multifunctional mechanism. One of the main directions of its development is the cereal marketing system, which predetermines the feasibility of agricultural production, the reliability of the country's grain and fodder supply, which has a significant impact on the efficiency of foreign trade. The problems of disparity in prices for commodity resources sold and grain products supplied to producers, and the development of production infrastructure remain unresolved. There is a lack of storage capacities for grain, high tariffs for services of elevators and grain receiving points, forcing agricultural producers to sell grain at low prices.
\end{abstract}


Аңдатпа. Астық нарығының тиімді жұмыс істеуі елдің азық-түлік қауіпсіздігін қамтамасыз етуге ықпал етеді. Мақсаты - астық өткізу жүйесін жетілдіру мәселесі қарастырылуда. Әдісmері - салыстырмалы талдау, статистикалық-экономикалық, логикалық, жалпылау. Нәтижелері - агроөнеркәсіптік кешенді дамыту басымдықтары контексінде астық ресурстарының әлеуетіне баға берілді. Қазіргі уақытта астықтың өткізу арналарының көлемі мен құрылымының өзгеруі байқалады: абсолютті көрсеткіштердің және оны мемлекетке өткізудің салыстырмалы үлесінің төмендеуі және еркін нарықта сатудың ұлғаюы байқалады. Дәнді дақылдарды сақтауға қатысты жағдай көрсетілген, бұл ірі элеваторлардың жұмысында агрохолдингтердің жұмыс істеуіне, негізінен астық егетін өңірлердің аумағында орналасқан ірі астық компаниялары мен трансұлттық корпорациялардың пайда болуына байланысты үрдістер белгіленгенін көрсетеді. Сонымен қатар көптеген ауыл тауар өндірушілерінің өз астық қоймалары жоқ, өткізу кооперативтеріне біріктірілмеген, бұл оларға жоғары сапалы дәнді дақылдардың ірі тауарлық партияларын қалыптастыруға, айналым шығындарын азайтуға мүмкіндік бермейді. Сонымен қатар, олар астық тазалау және астық кептіру техникасымен жеткілікті жабдықталмаған, нәтижесінде шикізат базистік кондицияларға дейін жете алмайды. Қортындылар - республика экономикасында басты орынға ие астық саласы-күрделі және серпінді дамып келе жатқан көпфункционалды тетік. Оны дамытудың негізгі бағыттарының бірі - сыртқы сауданың тиімділігіне айтарлықтай әсер ететін, ауылшаруашылық өнімдерін өндірудің орындылығын, елдің нан және жем-шөппен қамтамасыз етілуінің сенімділігін анықтайтын дәнді дақылдарды сату жүйесі болады. Сатылатын тауар ресурстары мен өндірушілерге жеткізілетін астық өнімдері бағасының сәйкессіздігі, өндірістік инфрақұрылымды дамыту проблемалары шешілмеген күйінде қалып отыр. Астық сақтауға арналған сыйымдылықтардың жеткіліксіздігі, ауыл шаруашылығы тауар өндірушілерін астықты төмен бағамен сатуға мәжбүрлейтін элеваторлар мен астық қабылдау пункттері қызметтерінің жоғары тарифтері орын алып отыр.

Аннотация. Эффективное функционирование зернового рынка способствует обеспечению продовольственной безопасности страны. Цель - рассматривается проблема совершенствования системы сбыта зерна. Методы - сравнительного анализа, статистико-экономический, логический, обобщения. Результаты - дана оценка потенциала зерновых ресурсов в контексте приоритетов развития агропромышленного комплекса. Отмечается, что в настоящее время наблюдаются изменения объемов и структуры сбытовых каналов зерна: снижение абсолютных показателей и относительной доли реализации его государству и увеличение продажи на свободном рынке. Показана ситуация с хранением зерновых, которая свидетельствует, что в работе крупных элеваторов обозначены тенденции, связанные с функционированием агрохолдингов, появлением крупных зерновых компаний и транснациональных корпораций, в основном расположенных на территории зерносеющих регионов. В то же время многие сельские товаропроизводители не имеют собственных зернохранилищ, не объединены в сбытовые кооперативы, что не дает им возможность формировать крупные товарные партии зерновых культур высокого качества, снижать издержки обращения. Кроме того, они недостаточно оснащены зерноочистительной и зерносушильной техникой, в результате сырье не подрабатывается до базисных кондиций. Выводы зерновая отрасль, занимающая ключевое положение в экономике республики - сложный и динамично развивающийся многофункциональный механизм. Одним из главных направлений ее развития является система сбыта злаковых, предопределяющая целесообразность производства сельскохозяйственной продукции, надежность хлебо- и фуражного обеспечении страны, оказывающая значительное воздействие на эффективность внешней торговли. Остаются нерешенными проблемы диспаритета цен на реализуемые товарные ресурсы и поставляемую производителям зерновую продукцию, развития производственной инфраструктуры. Имеют место недостаток емкостей для хранения зерновых, высокие тарифы на услуги элеваторов и хлебоприемных пунктов, вынуждающие сельскохозяйственных товаропроизводителей продавать зерно по низким ценам.

Key words: agro-industrial complex, regions, rural producers, commodity consignments of grain, production, storage, processing, marketing, grain products, marketing cooperatives.

Түйінді сөздер: агроөнеркәсіптік кешен, өңірлер, ауылдық тауар өндірушілер, астықтың тауарлық партиялары, өндіру, сақтау, қайта өңдеу, өткізу, астық өнімдері, өткізу кооперативтері.

Ключевые слова: агропромышленный комплекс, регионы, сельские товаропроизводители, товарные партии зерна, производство, хранение, переработка, сбыт, зернопродукты, сбытовые кооперативы.

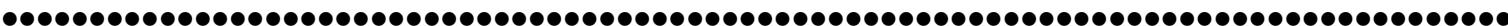

Шаруашылық жүргізудің экономикалық механизмі 
Introduction. Grain marketing system, directly affecting the economic interests of grain-producing farms, regions and the state, has a significant impact on the efficiency of grain farming and functioning of the grain market, largely predetermines the reliability of bakery and forage supply of the country, its food security.

It covers a wide range of issues arising in the process of production, storage, transportation, processing and sale of grain [1]. Relatively rapid transition of the agrarian sphere of economy to market relations, development of the grain market fundamentally changed the existing system of grain marketing in the country. They affected quantitative and qualitative indicators of realization, structural shifts in marketing channels and assortment of grain, organizational and legal forms and economic relations between all participants of grain movement from its direct producers to consumers.

In its turn, these changes were caused by the need to create a system of normative legal, economic and organizational conditions for effective functioning of the grain market and had its ultimate goal to increase efficiency of grain farming, orientation of grain production to meet the maximum needs of the country in it, creation of export resources of grain.

However, during the years of market transformations these tasks could not be fully realized. In addition, the abrupt changes that took place in the production and especially in the grain marketing system along with certain positive moments had negative consequences both for its direct producers and consumers and for the state. In the present situation sustainable functioning of the grain market should be realized on the basis of combination of market principles with state regulation of the market and purposeful support of its subjects.

Material and methods of research. Price situation on the grain market, connected with disparity of prices for sold grain and industrial goods purchased by grain-producing farms as well as disproportion between demand for grain and its supply, is considerably aggravated by absence of highly effective and well-organized forms of grain sale and weak development of other elements of infrastructure and logistical support of the grain market. Because of constant inconsistency and mismatch of actions in the system of commodity movement there is multilinking, presence of a large number of intermediaries in grain trade, poor awareness of the grain market participants, quantitative and financial transparency of commodity flows of grain and its products by separate subdivisions of grain product subcomplex and regions of the country is not provided.

Despite the adoption by the state of the course to liberalize the grain market, modern methods of its influence on it were not very diverse. They were reduced mainly to setting prices for grain purchased for regional food funds, which is a small share in its total commodity volume [2].

The scattered organizational and economic measures of state regulation of the grain market, provided by the state programs for the development of agriculture and regulation of markets of agricultural products, raw materials and food, did not give proper positive effect either.

Results and their discussion. Lack of a clear economic mechanism of agricultural producers orientation in the changed demand caused difficulties with the sale of certain types of grain. Price formation on the grain market still mainly reflects its chaotic movement, since prices for the same type of grain differed by regions depending on its marketing channel 1.5-2 times and more.

Their large amplitude of fluctuations by regions of the country indicates that its grain market consists of a number of local markets, largely isolated from each other.

High costs for transportation of grain, which destroy unified market space, increase fluctuation of prices for grain and products of its processing, and destabilization of grain production also contributed to this [3].

The peculiarity of the situation on the grain market also consisted in the fact that while reducing the production and procurement of grain inside the country and abandoning largescale imports, large-scale exports of grain were carried out, which, to some extent, narrowed its domestic resources. Eliminating such imports of grain mainly by sharply reducing the use of grain for feeding livestock and poultry, more economical consumption of it for food purposes. A variety of forms of grain sales became available: on a contractual basis, under contracts, through cooperatives, stock exchanges. All that manifested itself in considerable change of volumes and structure of grain sale channels: decrease of absolute volume and relative share of grain sale to the state and increase of its sale on the free market.

In Kazakhstan the total sown area of crops in 2021 amounted to 23 million hectares, 322 thousand hectares more than in 2020. Cereals and leguminous plants covered 15.9 million hectares (including wheat - 12.9 million hectares), oilseeds - 3.1 million hec- 
tares, vegetables and potatoes -473.8 thousand hectares, cotton - 109.7 thousand hectares, sugar beets - 21.7 thousand hectares, fodder crops - 3.2 million hectares.

In Joint Stock Company "National Company "Food Contract Corporation" (further Foodcorporation) delivered 119 thousand tons of grain crops in 2021, the reserve stock of grain is 426.3 thousand tons. The volume of grain supply in 2021 to the resources of Foodcorporation is determined in the amount of 769.4 thousand tons, the prices for the purchase of wheat of the 3rd class - 103-107 thousand tenge, depending on quality, for the wheat of the 4th class - 98 thousand tenge, for the barley of the 2nd class - 87 thousand tenge. JSC "NC "Food Contract Corporation" has determined the market price in accordance with the current market conditions, allowing agricultural producers to compensate for losses associated with dry summer and a general decline in yields. Purchase prices for 2021 grain are $24 \%$ higher than the purchase prices announced for 2020.

The entire volume of grain of the 2021 harvest will be sent to the domestic market at a fixed price to flour-milling organizations, poultry and livestock farms in order to stabilize prices for their final products. To ensure the return of grain under forward purchase contracts Foodcorporation announced the following prices: wheat class 3 (gluten 23\%) - 103000 tenge (\$242) including VAT (in 2020 the price was 83000 tenge). JSC "NC "Food Contract Corporation" held forward purchase of agricultural products, thanks to which the contracted volume of grain supply in the amount of 769.5 thousand tons, the reserve stock of 448 thousand tons. Grain if necessary will be sent to the domestic market to stabilize and ensure food security. The total storage capacity of grain in the country is 27.5 million tons including 12 million tons at grain receiving enterprises and 15.5 million tons at rural producers.

In Canada $31.6 \%$ decrease in the gross harvest of wheat is expected compared to the last year. In the United States of America the wheat harvest is forecast to decrease by $4.4 \%$ compared to last year; in the Russian Federation a decrease of $15 \%$ in the gross harvest of wheat is forecast [4].

Trends in the distribution channels of grain are mainly characteristic of the structure of sales of certain types of grain as well. The smaller the production becomes, the stronger the desire of grain-producing farms to restrain the sale of grain during harvesting in the expectation to get a higher price for it in the future. The annual situation on the grain market is characterized by sharp annual fluctuations of market conditions and a weak role of the state in maintaining market equilibrium. Its possible growth, taking place mainly on the side of cattle breeding, is limited by solvency of population, economic inaccessibility of meat and dairy products for the main part of it.

Kazakhstan will form a permanent fodder grain fund, a road map for the development of fodder production, which provides for the formation of a permanent fodder grain fund on the basis Foodcorporation, the introduction of temporary quantitative restrictions (quotas) or a ban on the export of roughage and fodder grain. It was not reported that the JSC "NC "Food Contract Corporation" has set prices for grain to ensure its return on contracts for forward purchases [5].

The Government has approved the $\mathrm{Na}$ tional project on development of agri-industrial complex of the Republic of Kazakhstan for 2021-2025 (further National project) 582 investment projects for 4.1 trillion tenge are to be realized in five years. The National project, which involved experts from the UN's Food and Agriculture Organization (FAO) and representatives of agricultural unions, associations and scientists, set as its main goal the increase of agricultural productivity by 2.5 times.

The second direction - providing Kazakhstan with main domestic foodstuffs; the third increasing export of agro-industrial complex products by 2 times, raising the share of processed products to $70 \%$ in it; the fourth - stable increase of income of 1 million rural residents through the formation of seven large ecosystems and implementation of investment projects.

Availability of a large number of agricultural producers engaged in the cultivation of grain crops, different sizes of grain wedge and volumes of grain produced by them, unequal specialization of grain-producing farms and their economic status in combination with the needs for grain from numerous consumers determine the diversity of grain marketing channels.

At the same time different factors influence the choice of grain sales channel, to which, in particular, one can refer: volumes of commodity batches, types and consumer properties of grain, price level and terms of payment for grain, transportation costs for its transportation, etc.

But, as a rule, large and economically strong grain producers able to form large commodity lots of grain independently have the greatest freedom and opportunity to 
choose more profitable channel of grain sales on the primary grain market.

As a rule, large domestic and foreign grain companies with grain storage capacity and processing capacity are engaged in interregional supply and export of grain [6].

For example, the largest grain companies own one-third of the grain storage capacity and have about the same share of the flour market. The concentration of export grain is much higher, with two-thirds of its volume in grain companies, most of which are controlled by transnational corporations [7].

Grain Union of Kazakhstan offers 10\% of grain from export consignment to resources of JSC "NC "Food Contract Corporation" at set price at the level of 105 thousand tenge/ton, while commercial price on the market is 120 thousand tenge per ton, from each ton exporter loss will be 1.5 thousand tenge, but they are ready to bear this social burden in order to preserve perspectives of the industry.

Under refunds on forward contracts Foodcorporation will receive 738 thousand tons of wheat from farmers. In addition, the Government has allocated it funds to purchase 200 thousand tons of food grain on the commercial market, wheat is also enough to meet all domestic needs of Kazakhstan. The total amount of resources will exceed 938 thousand tons, has an emergency food reserve of 500 thousand tons, which is stored in case of unforeseen natural disasters and can be unpacked only by special decision of the authorities.

The wheat harvest in 2021 is estimated at 10.5 million tons, significantly lower than in 2020 (13.6 million tons). Export potential of Kazakhstan in wheat and flour in grain equivalent is estimated at 6.1 million tons, sending JSC "NC "Food Contract Corporation" 10\% of this volume, its reserves will be replenished by 610 thousand tons.

Export potential for the 2021/2022 marketing year is estimated at 7.9 million tons, the domestic food requirement of 2.7 million tons. In January - August 2021, 3.6 million tons of wheat and meslin worth $\$ 821.4$ million were exported, which is $124 \%$ compared to the same period in 2020.

From the bakery enterprises of Akmola region shipped 256.9 thousand tons of grain for export to neighboring and far-abroad countries and other regions of Kazakhstan. Of the 26 importer countries, 8 states purchased grain, the largest amount shipped to Uzbekistan (68.7 thousand tons), Tajikistan (51.3 thousand tons), Iran (44.8 thousand tons), China (24.1 thousand tons). 3.2 thousand tons was supplied to Azerbaijan, 5.8 thousand tons to Afghanistan, 4.4 thousand tons to the Russian Federation and 1.5 thousand tons to Turkmenistan. LLP "Astykkojmalary" includes 4 grain receiving enterprises (Akmola and North Kazakhstan regions), which include silos and warehouses for outdoor storage of grain with capacity from 70 to 192 thousand tons, highcapacity grain-cleaning and drying equipment. Due to this, processing of grain coming directly from the field can be carried out.

The main normative legal documents defining economic relations of the parties when selling grain are contracts and purchase and sale agreements. Contracts are concluded when selling grain to the state food funds.

Some grain is also sold without contracts, since many producers do not have their own granaries and are not united in marketing cooperatives, which would give them the opportunity to independently form large commercial batches of grain of higher quality and reduce the cost of circulation. They are poorly equipped with grain cleaning and drying machinery, which does not allow them during the harvesting period to process grain to basic conditions, and when it is possible to process it, in the absence of developed exchange trade of grain under standardized contracts to sell it at a price that compensates the additional costs associated with improving the quality of grain.

This forces them to sell the bulk of commercial grain in the harvesting season at reduced prices to trade intermediaries or agents of large grain companies for cash, without incurring costs for transportation and processing of grain.

There are reasons for weakening of the connection between prices and quality characteristics of grain when producers are not economically interested in improving the quality of grain even when selling it into regional and intervention funds.

These reasons include: reduction of the level of agricultural technology of crops cultivation combined with the deteriorating material and technical base to bring the grain to the basic conditions; arbitrarily set, increased prices for the services of elevators and bakeries, as well as the dominant subjectivism in assessing the quality characteristics of grain [8].

Due to these and a number of other reasons, when selling grain to commercial structures, many agricultural producers do not care about its processing, which leads to mixing of different-quality batches of grain, loss in price, excessive transportation costs [9]. Significant dispersion of prices for the same types of grain 
even within the boundaries of one administrative territory indicates a weak link between prices and supply and demand. Another significant blocking factor in the development of the grain market and sales of grain is the work of grain elevators and bakery enterprises.

Their hasty corporatization in most cases has deteriorated the state of material and technical base.

Thus, according to technical support some elevators are close to the world level, the rest require modernization, without which it is impossible to improve significantly the conditions of storage and quality of grain. At the same time there is a high cost of grain storage, since in many grain-producing regions elevators are loaded less than by half and a significant part of grain remains in farms, most of which are not able to store grain properly, which leads to unreasonable quantitative and qualitative losses and high costs. The issue of grain storage has become acute for agricultural producers due to the reduction of state procurement of grain, privatization of elevators and grain receiving enterprises [10].

Having obtained the right to perform their economic activities independently, elevators and bakery enterprises in the conditions of decreasing volumes of harvested grain sharply increased the payment for its storage, making this rent unprofitable for the majority of commercial grain producers.

With available financial resources, some grain producers began to build their own granaries, others began to store commercial grain on their own in poorly mechanized, often unsuitable containers.

Both in the first and in the second cases it happened in the presence of empty capacities of elevators and bakery enterprises, which from the position of the state is ineffective, since it led to increased grain losses, reduction of its quality, irrational expenditure of material, labor and financial resources. Many unsolved problems arise in the economic relations between the elevators and producers of commercial grain, performance of control functions over the monitoring of its quality, the possibility of using the storage certificates in the elevators work, the state support of the grain storage system by the example of the Canadian elevators functioning.

The current situation with grain storage in recent years shows that there are two tendencies in the development of large grain elevators. The first one is connected with the functioning of agricultural holdings, one part of which concentrates granaries and controls the whole production business-process, while the other part gets rid of elevator assets explaining it by high risks to a certain extent connected with unpredictability of the state policy in relation to production and sales of grain. The second tendency is connected with the appearance of big foreign grain companies and transnational corporations on the grain market and their activity in buying elevators for exporting domestic grain.

This is contributed by elevators' excessive capacities in some regions and their relatively low cost, favorable geographical location to foreign grain markets as well as by comparatively liberal national legislation allowing them to enter the strategic grain-production and commodity-providing network of the country under conditions of high investment capacity of the grain market. Large foreign grain companies and transnational corporations are competitors for domestic grain companies that export russian grain. Creating elevator networks they have the opportunity to form large homogeneous quality grain lots, reduce costs due to the effect of concentration and different kinds of risks for the owners of grain, improve elevator management.

Storage of grain at elevators is beneficial to the owner of the grain not only because it guarantees its almost complete quantitative and qualitative safety, but also because, if the grain owner wishes, the elevators can give him a storage certificate, the security part of which is recognized by banks for granting loans for the period of storage of the grain at the elevator. The similar practice exists in many countries with developed grain economy and grain market.

Main problems, hindering development of grain storage and processing sphere, are 50$80 \%$ wear of the main production assets, high dependence on foreign suppliers of equipment due to deficiency of domestic equipment, and low profitability of this activity, which does not exceed $1-3 \%$. It is these factors that largely caused the need to solve them through the implementation of industry specific long-term programs and investment projects. In the nearest future due to different reasons essential growth and renewal of material-technical basis of post-harvest grain processing and storage is not expected in grain-producing farms.

Numerous questions of development of grain storage and processing require complex solution in the first place within framework of realization of departmental target program of development of grain sector and grain market within framework of state programs. The para- 
dox consists in the fact that grain farming is one of few sub-branches of country's agriculture, which produces strategically important product what is the grain, until recently had no own development program.

Moreover, within the framework of state programs it is extremely difficult to provide all necessary measures for sustainable development of grain economy and grain market, since their implementation to a certain extent is the competence of the country's subjects and economic entities. This circumstance only strengthens the need for the development and implementation of the state target program for the development of grain economy and the grain market in the country.

\section{Conclusions}

1 Grain sales have a significant impact on the efficiency of grain farming and the functioning of the grain market and predetermine the reliability of bakery and forage supply of the country and its food security.

2. Various forms of grain sales: on a contractual basis, under contracts, through cooperatives, exchanges manifested themselves in a significant change in the volume and structure of grain sales channels in reducing the volume and share of grain sales to the state and increasing its sales on the free market.

3. Many grain producers do not have their own granaries and are not united in marketing cooperatives, which would give them the opportunity to independently form large commercial batches of grain of higher quality, reduce the cost of circulation, poorly equipped with grain cleaning and drying technology, which does not allow them during the harvesting period to process grain to basic conditions.

4. Development of grain storage and processing requires a complex solution in the first place within the framework of the target program of grain farming and grain market development. Grain farming is one of few subsectors of agriculture of the country, which produces strategically important product such as grain, until recently did not have its own development program.

\section{References}

[1] Алтухов, А.И. Сельскохозяйственному производству страны необходима новая концепция размещения и специализации // Экономика сельскохозяйственных и перерабатывающих предприятий. -2019.- № 8.- С.7-14.

[2] Tireuov, K. Integration processes - the component of the effective implementation of public-private partnerships / K. Tireuov, S. Mizanbekova, I. Pechenaya // Problems of AgriMarket. -2021. - N. 2. - P.70- 78.
[3] Алтухов, А.И. Парадигма продовольственной безопасности России: монография / А.И. Алтухов. - М.: Фонд «Кадровый резерв», 2019. - $682 \mathrm{c}$

[4] Узун, В.Я. Роль экспорта и импорта в развитии сельского хозяйства России / В.Я. Узун, Е.А. Шишкина.//Ккономика сельскохозяйственных и перерабатывающих предприятий. - 2020. - №2.-С.13-20.

[5] Мизанбекова, С.К. Зерновое хозяйство - основа функционирования зернопродуктового подкомплекса / С.К. Мизанбекова, Б.Б. Калыкова, Д.А. Айтмуханбетова // Проблемы агрорынка- 2021.-№ 2.- С.130- 137.

[6] Быков, А.А. Экспорт зерна и продуктов его переработки на примере Сибирского федерального округа: сложившаяся ситуация, позитивные процессы /А.А. Быков //Проблемы агрорынка.- 2021.- №2.- С.138-146.

[7] Бабин, В. Бережливое производство как внутренний фактор устойчивого развития аграрного экспорта / В.Бабин, Ю.Бабина //АПК: экономика, управление. - 2020. -№1.C.16-27.

[8] Гусаков, Е. Резервы повышения устойчивости и алгоритм экспортоориентированной кластерной политики АПК/ Е. Гусаков //Аграрная экономика.- 2019.- №8. - С. 4549.

[9] Анисимова, О.С. Пути обеспечения управления сбытом продукции растениеводства / О.С. Анисимова, И.В. Ткаченко // Фундаментальные исследования.- 2020.- № 11. - C. 26-31.

[10] Изтаев, А.И. Инновационные технологии и логистика перерабатывающих производств АПК / А.И. Изтаев, Т.К. Кулажанов, А.Д. Сапарбаев.- Алматы: ТОО «Фортуна Полиграф», 2019. - 752 с.

\section{References}

[1] Altuhov, A.l. (2019). Sel'skohozjajstvennomu proizvodstvu strany neobhodima novaja koncepcija razmeshhenija i specializacii [Agricultural production of the country needs a new concept of location and specialization]. Jekonomika sel'skohozjajstvennyh ipererabatyvajushhih predprijatij - Economy of agricultural and processing enterprises, 8, 7-14[in Russian].

[2] Tireuov, K., Mizanbekova, S. \& Pechenaya, L. (2021). Integration processes - the component of the effective implementation of public-private partnerships. Problemy agrorynkaProblems of AgriMarket, 2, 70- 78[in English].

[3] Altuhov, A.l. (2019). Paradigma prodovol'stvennojbezopasnosti Rossii: monografija [The paradigm of food security in Russia: monograph] Moskva: Fond «Kadrovyjrezerv», 682 s. [in Russian].

[4] Uzun, V.Ja. (2020). Rol' jeksporta i importa $v$ razvitii sel'skogo hozjajstva Rossii [The role of exports and imports in the development of agriculture in Russia]. Jekonomikasel'sko- 
hozjajstvennyh $i$ pererabatyvajushhih predprijatij-Economy of agricultural and processing enterprises, 2, 13-20[in Russian].

[5] Mizanbekova, S.K., Kalykova, B.B. \& Ajtmuhanbetova, D.A. (2021). Zernovoe hozjajstvo - osnova funkcionirovanija zernoproduktovogo podkompleksa [Grain farming is the basis for the functioning of the grain-product subcomplex]. Problemy agrorynka-Problems of AgriMarket, 2, 130-137[in Russian].

[6] Bykov, A.A. (2021). Jeksport zerna i produktov ego pererabotki na primere Sibirskogo federal'nogo okruga: slozhivshajasja situacija, pozitivnye process [Export of grain and products of its processing on the example of the Siberian Federal District: the current situation, positive processes]. Problemy agrorynkaProblems of AgriMarket, 2, 138-146 [in Russian].

[7] Babin, V., Babina, Yu. (2020). Berezhlivoe proizvodstvo kak vnutrennij factor ustojchivogo razvitija agrarnogoj eksporta [Lean production as an internal factor of sustainable development of agricultural exports]. $A P K$ : jekonomika, upravlenie- AIC: economics, management, 1, 16-27 [in Russian].

[8] Gusakov, E. (2019). Rezervy povyshenijausto jchivosti i algoritmj eksportoorientirovannoj klasterno jpolitiki APK [Reserves for increasing stability and the algorithm of export-oriented cluster policy of the agro-industrial complex] Agrarnaja jekonomika-Agrarian Economics, 8, 45 49[in Russian].

[9] Anisimova, O.S., Tkachenko, I.V. (2020). Puti obespechenija upravlenija sbytom produkcii rastenievodstva [Ways of ensuring management of sales of crop production.]. Fundamental'nye issledovanija-Fundamental Research, 11, 2631 [in Russian].

[10] Iztaev, A.I., Kulazhanov, T.K. \& Saparbaev, A.D. (2019). Innovacionnye tehnologii i logistika pererabatyvajushhih proizvodstv APK [Innovative technologies and logistics of agroindustrial complex processing industries]. Almaty: TOO «Fortuna Poligraf», 752 [in Russian].

Information about authors:

Mizanbekova Salima -The main of author; Doctor of Economic Sciences RK, RF, Professor; Professor of the Department of Management and Organization of Agribusiness; Kazakh National Agrarian Research University; 050010 Abay ave., 8, Almaty, Kazakhstan; e-mail: salima-49@mail ru; https://orcid.org/ 0000-0002-7602-9710

Kalykova Bakhyt; Candidate of Economic Sciences, Associate Professor; Professor of the Department of Management and Organization of Agribusiness; Kazakh National Agrarian Research University; 050010 Abay ave., 8, Almaty, Kazakhstan; e-mail: kalykova_b_b@mail.ru; https://orcid.org/0000-00018020-0392

Turashbekov Nurbol; Ph.D student of the Department of Management and Organization of Agribusiness; Kazakh National Agrarian Research University; 050010 Abay ave., 8, Almaty, Kazakhstan; e-mail: nturashbekov@bk.ru; https://orcid.org/0000-00021364-111X

\section{Авторлар туралы ақпарат:}

Мизанбекова Салима Каспиевна - негізгі автор; ҚР, РФ экономика ғылымдарының докторы, профессор; «Агробизнесті басқару және ұйымдастыру» кафедрасының профессоры; Қазақ ұлттық аграрлық зерттеу университет; 050010 Абай данг., 8, Алматы қ., Қазақстан; e-mail: salima-49@mail ru; https://orcid.org/ 0000-0002-7602-9710

Қалыкова Бақыт Баймұратқызы; экономика ғылымдарының кандидаты, қауымдастырылған профрессор; «Агробизнесті басқару және ұйымдастыру» кафедрасының профессоры; Қазақ ұлттық аграрлық зерттеу үниверситеті; 050010 Абай данг., 8, Алматы қ., Қазақстан; e-mail: kalykova_b_b@mail.ru; https://orcid.org/0000-0001-8020-0392

Турашбеков Нурбол Абдисаттарович; Ph.D докторанты «Агробизнесті басқару және ұйымдастыру» кафедрасының; Қазақ ұлттық аграрлық зерттеу үниверситеті; 050010 Абай данг., 8, Алматы қ., Қазақстан; e-mail: nturashbekov@bk.ru; https://orcid.org/0000-00021364-111X

\section{Информация об авторах:}

Мизанбекова Салима Каспиевна - основной автор; доктор экономических наук РК, РФ, профрессор; профеессор кафедры «Менеджмент и организация агробизнеса»; Казахский национальный аграрный исследовательский университет; 050010 пр. Абая, 8, г.Алматы, Казахстан; e-mail: salima-49@mail ru; https://orcid.org/ 0000-0002-7602-9710

Калыкова Бахыт Баймуратовна; кандидат экономических наук, ассоциированный профессор; профессор кафедры «Менеджмент и организация агробизнеса»; Казахский национальный аграрный исследовательский университет, 050010 пр. Абая, 8, г.Алматы, Казахстан; e-mail: kalykova_b_b@mail.ru; https://orcid.org/0000-0001-8020-0392

Турашбеков Нурбол Абдисаттарович; докторант Ph.D кафедры «Менеджмент и организация агробизнеса»; Казахский национальный аграрный исследовательский университет, 050010 пр. Абая, 8, г.Алматы, Казахстан; e-mail: nturashbekov@bk.ru; https://orcid.org/0000-00021364-111X 